\title{
LIVING WITH MENTAL DISORDER IN CHILDHOOD: FEELINGS AND REACTIONS OF THE FAMILY
}

\author{
Jéssica Batistela Vicente², Sonia Silva Marcon ${ }^{3}$, Ieda Harumi Higarashi ${ }^{4}$
}

\footnotetext{
${ }^{1}$ Paper taken from the thesis - Mental illness in childhood: Family experiences, presented to the Graduate Nursing Program at Universidade Estadual de Maringá (UEM) in 2013.

${ }^{2}$ M.Sc. in Nursing. Graduate Nursing Program at UEM. Maringá, Paraná, Brazil. E-mail: jessicabatistela@hotmail.com

${ }^{3}$ Ph.D. in Nursing Philosophy. Faculty, Nursing Department at UEM. Maringá, Paraná, Brazil. E-mail: soniasilva.marcon@gmail. com

${ }^{4}$ Ph.D. in Education. Faculty, Nursing Department at UEM. Maringá, Paraná, Brazil. E-mail: ieda1618@gmail.com
}

\begin{abstract}
Descriptive study with a qualitative approach, involving 14 families of children with mental disorders assisted at the Psychosocial Child Care Center of Maringá, Paraná, Brazil. The objective was to understand the experiences, feelings and reactions of families of child with mental disorder. Data were collected from January till April 2013 through open interviews and then analyzed using thematic Content Analysis. Two categories emerged "Living with mental disorder in childhood: a daily battle" and "Feeling and reacting: experiencing the mental disorder in childhood". It is concluded that the family needs to understand the disease to accept it and thus learn how to live with it, and it is up to the nurse to provide support in order to face the difficulties.
\end{abstract}

DESCRIPTORS: Family. Child health. Mental health. Nursing.

\section{CONVIVENDO COM O TRANSTORNO MENTAL NA INFÂNCIA: SENTIMENTOS E REAÇÕES DA FAMÍLIA}

RESUMO: Estudo descritivo de abordagem qualitativa, realizado junto a 14 familiares de crianças com transtornos mentais, atendidas no Centro de Atenção Psicossocial Infantil de Maringá, Paraná, tendo como objetivo compreender as vivências, os sentimentos e as reações de famílias de crianças com transtorno mental. Os dados, coletados no período de janeiro a abril de 2013, por meio de entrevista aberta, foram submetidos à análise de conteúdo, modalidade temática, da qual emergiram duas categorias: "Convivendo com o transtorno mental na infância: uma batalha diária" e "O sentir e o reagir: vivenciando o transtorno mental infantil". Conclui-se que a família precisa compreender a doença para aceitá-la e, assim, aprender a conviver com ela, e cabe ao enfermeiro oferecer suporte para o enfrentamento das dificuldades. DESCRITORES: Família. Saúde da criança. Saúde mental. Enfermagem.

\section{CONVIVIENDO CON EL TRASTORNO MENTAL EN LA INFANCIA: SENTIMIENTOS Y REACCIONES DE LA FAMILIA}

RESUMEN: Estudio descriptivo de abordaje cualitativo, realizado junto a 14 familiares de niños con trastornos mentales atendidos en el Centro de Atención Psicosocial Infantil de Maringá, teniendo como objetivo comprender las vivencias, los sentimientos y reacciones de la familia de los niños con trastorno mental. Los datos, recolectados durante el período de enero a abril de 2013, por medio de entrevista abierta, fueron sometidos al análisis de contenido, modalidad temática, de la cual emergieron dos categorías: "Conviviendo con el trastorno mental en la infancia: una batalla diaria" y "El sentir y el reaccionar: viviendo el trastorno mental infantil". Se concluye que la familia necesita comprender la enfermedad para aceptarla y, así, aprender a convivir con ella, y compete al enfermero ofrecer soporte para el enfrentamiento de las dificultades.

DESCRIPTORES: Familia. Salud del niño. Salud mental. Enfemería. 


\section{INTRODUCTION}

The psychiatric reform, aiming to change public care in Mental Health, is aimed at guaranteeing the population's access to services and respect for their rights and freedom, prioritizing contact with the family and the community. It is estimated that $3 \%$ of the population is affected by severe and continuing mental disorders nowadays, and that approximately $12 \%$ needs some mental health care, including children and adolescents in these percentages. ${ }^{1}$

As a result of technological advances, children who used to be exposed to the biological risk of dying experience the stress of increased urbanization, violence, changes in the family structure, making them vulnerable to the emergency of early mental disorders. ${ }^{2}$ The prevalence of mental disorders in childhood has increased and their diagnosis is difficult and doubtful. A study developed in the South of Brazil involving this population evidences the greater prevalence of attention disorder deficits and disruptive behaviors, followed by anxiety and learning disorders. ${ }^{3}$

Independently of the type of mental disorder, this class of diseases clearly shakes up the family structure. Changes take place in the family's routine, habits and customs, requiring adaptations to this new situation, in most cases permeated by stigma and prejudice. These modifications can cause a physical and emotional burden for the family caregiver. ${ }^{4-5}$

These families experience a state of anguish and constant concerns and, sometimes, feel guilty because of their relative's disease, at the same time as they face moral and social difficulties when they are confronted with the need to delegate care for their loved one to a health institution, experiencing frustrations because of the duty not complied with and the life expectancy they had dreamt for that person. ${ }^{6}$

To attend to that specific population, in 2002, the Psychosocial Care Centers for Childhood and Adolescents (CAPS-i) were set up, aimed at attending to children and adolescents with mental disorders and grant psychological support to the family members. ${ }^{3}$

Family support and each family member's competences directly influence the way the child copes with the disease. In that context, the need is evidenced to assist these families who, powerless in view of the situation, lack support and attention from health professionals, and particularly from nurses, so that their attitudes and reactions towards the disease are aimed at helping the child to better cope with this condition.

Although the problems experienced in these families are common, each family has its individualities and peculiarities in the form of feeling, reacting and expressing what they experience in view of different situations. And, when they listen to and get to know these families, the nurses can better guide them, clarifying the doubts about the disease and thus contributing to better contact and acceptance of the mental illness. Appropriately guided family members can serve as the support base for care, so that the mental patient spends most of the time in contact with the social and school friendship circle. ${ }^{7}$

Today, family-centered care is the base for mental health care. In this concept, the family members are considered partners and co-accountable for their loved one's treatment. With a view to a successful partnership, the family equally needs to be taken care of and supported to cope with the difficulties that emerge in daily life with the mental illness. Therefore, getting to know each family reality and contact with the child with mental illness is fundamental for the appropriate professional approach of these families.

In view of the above, the objective in this study was to understand the experiences, feelings and reactions of families of children with mental illness.

\section{METHOD}

A descriptive study with a qualitative approach was undertaken in Maringá-PR, involving family members of children attended at the city's CAPS-i.

The criteria to select the participants were: living in the city where the study was undertaken, being a relative and preferred caregiver of children attended in the CAPS-I, who has been diagnosed or monitored for more than one year, considering that a recent diagnosis start of monitoring could interfere in the achievement of the study objective. The definition of childhood established in the Child and Adolescent Statute (ECA) was used, that is, a person of up to 12 years. ${ }^{8}$

The field research took place at two times: in the first, the researcher sat in on some therapeutic groups held at the CAPS-I with the service's preliminary consent, so as to get to know the families 
and bond. At the time, four therapeutic groups were active at the service, two of them exclusively for family members and caregivers and children with mental disorders. These groups meet every two weeks and each session takes about one hour. Later, home visits were made to collect data through an open interview. The home was chosen as the place of study because, in this environment, the family would feel more comfortable to tell the story.

Professionals from the service indicated the research participants, who intermediated the initial contact. At an appropriate time, the subjects received further information on the research objectives and were invited to participate in the study. After their acceptance, the home visits were scheduled to hold the interviews. Eleven families participated in the study, totaling 14 interviewees, as there was no impediment on having more than one family caregiver take part in the study.

The data were collected between January and April 2013 and the interviews took approximately 40 minutes. The question guiding the interview was: "Tell us about your family member's (name of the child) disease, since the diagnosis/start of monitoring until today".

The interviews were recorded and complemented using information from the field diary, which were registered soon after the end of the interviews, even before their transcription. In this diary, besides some personal impressions, the researcher's observations were registered regarding aspects the recording did not capture: non-verbal language and gestures, facial expressions.

To analyze the data, information on the sample characteristics was described and the interview data were analyzed through thematic content analysis. The interviews were fully transcribed for analysis, involving three phases: pre-analysis, exploration of the material and data treatment. ${ }^{9}$

In the pre-analysis, floating reading took place, the reports were chosen, the hypotheses were formulated, the indices were chosen and indicators were elaborated to support the interpretation. In the exploration phase of the material, groups and associations were found that complied with the study objectives, revealing the categories. In the treatment phase of the results, inferences were made and the results found were interpreted. ${ }^{9}$

The development of the study complied with the guidelines of National Health Council Resolution 466/2012. Therefore, the research proj- ect received approval from the Maringá Health Secretariat and the Permanent Ethics Committee for Research involving Human Beings from Universidade Estadual de Maringá (Opinion 162.598/2012). All participants signed two copies of the Free and Informed Consent Form and, to guarantee anonymity, their reports were identified using names of flowers, alluding to the delicacy and beauty of the histories reported.

\section{RESULTS AND DISCUSSION}

Among the 14 family members who participated in the study, 13 were women, being ten mothers and three grandmothers. The only participating male was the father of a child with mental disorder. Only three children already possessed a defined diagnosis (Hyperactivity, Attention Deficit, Bipolar Disorder), although all of them were under treatment for more than one year (average one year and seven months), evidencing the great difficulty to diagnose the childhood mental disorder.

The participants' ages ranged between 25 and 74 years (mean 39 years), being six married, six divorced and two widowed. In general, their education level was low, one was illiterate and six did not complete primary education. Among the others, one completed primary education, four completed secondary education and two did not complete secondary education.

The families' monthly income ranged between $\mathrm{R} \$ 300.00$ and $\mathrm{R} \$ 3,000.00$ (mean $\mathrm{R} \$ 1,255.00$ ). One of the families did not have an income, but only counted on help from the paternal family. In eight families, only one person was responsible for the family income; in the remainder, two persons were. The referred professional activities were: housewife (four), domestic servant (three), pensioner (two), seamstress, concierge, administrative aid, meat salter, self-employed. Six interviewees reported having left their job to exclusively focus on care for the child.

Based on the data analysis, two categories were configured: "Living with the mental disorder in childhood: a daily battle", and "Feeling and reacting: experiencing the childhood mental disorder".

\section{Living with the mental disorder in childhood: a daily battle}

The health professionals consider the family an ally in care.${ }^{10}$ Nevertheless, for the family to act 
appropriately and serve as a base for the implementation of mental health care, it is important, in the first place, to identify the difficulties deriving from life with the child with a mental disorder.

In the presence of a chronic disease in childhood, the family needs to reorganize its daily life. The health team is responsible for acknowledging the difficulties the family copes with and having resources that help in the process of coping and adapting to this situation. ${ }^{11}$

Among the difficulties usually faced in this daily reality, the conflicting relationship between the child with the mental disorder and its parents, siblings and colleagues from school, largely permeated by aggressiveness.

He lives well with me, but he slaps his father in the face, he says like: 'I'm going to kill you!' You know?... These things like... and I say: 'Son, go and play a little with the children'. And if there's another child, he chases it [sends it away], he doesn't want the children to come and play with him. And generally children want to play, and he doesn't, either he goes to the television or to the computer, he likes to stay alone (Azaléa, mother).

Azaléa's statement reveals the concern with her son's aggressive attitudes towards his father. At the time of the statement, the participant demonstrated sadness and her tone of voice evidenced fear about the situation, that is, the unknown universe that is the mental disorder. At the same time, the mother demonstrates true interest and expectation with regard to her son's socialization, stimulating him to relate with other children and getting frustrated at each refusal.

The aggressive behavior is the main cause of emergency psychiatric care in childhood and adolescence, but it is not always related with the presence of mental disorder, but can be reactive to situations of family, social or personal crisis. ${ }^{12}$

The child's aggressiveness tends to scare the caregivers as, normally, they are not appropriately prepared to cope with this kind of behavior, mainly concerning its repercussions for the family dynamics. The disease is the cause of conflicts and limits social life, and the family is the possible core of knowledge exchange. ${ }^{7}$ The nurse should be an agent of transformation in these contexts, empowering these families with knowledge on the mental disorders and thus contributing to relieve the suffering deriving from the daily difficulties.

You can't leave him near my youngest son, and when he gets home from school, the little one's already at home [...]. He gets near the little one and the little one starts crying in a way, in a way that's terrifying [...] and the little one goes with his mouth open to bite him. He's already caught a sock and put it over the boy's nose, I caught him closing it off! You can't leave him alone, he doesn't get along well with his siblings, oh dear! (Rosa, mother).

Rosa's testimony clearly shows the fear of her son's aggressive attitudes, creating a constant climate of tension for the caregiver, besides the need for constant alertness to any attitude of the child, afraid that the child might hurt his siblings.

Violence among siblings is the most common form of family violence and different individual, family and contextual factors contribute to its occurrence and maintenance. The high frequency of these behaviors evidences that this reality lacks further attention, as the relationship among siblings is one of the most long-lasting and extremely important in the course of a person's life. ${ }^{13}$

The child's aggressive behavior makes interpersonal relationships more difficult, making the child be no longer accepted in the social circle, as demonstrated in Acácia's statement.

He used to fight a lot with his sister, with classmates, with cousins. With us, older people, he had an answer to everything but wasn't aggressive. At school he used to hit the children, a lot! Now he's having friends, because last year he hadn't, because they were afraid of getting close to him (Acácia, mother).

The child's aggressiveness is a cause of great family concern and frequently constitutes the main motive to seek help from health services. The caregiver starts coping with the child's unpredictable behaviors on a daily base, which shakes up his/ her social expectations, causing uncertainties and difficulties at the heart of the family. ${ }^{4}$ In many cases, the child shows to be a burden for the caregiver, making him/her seek help from health services. At that moment, when professional support is necessary for the child and the family, nursing can act through interventions in the context of the Family Health Strategy or the CAPS-i. ${ }^{4}$

If he continues like that, he's going to get very rebellious! So, as one says, either he's gonna kill or he's gonna die early, you see? Because 'bold' people like that die early. So he's going to be that kind of person who'll get in trouble with anyone 'real easy' (Cravo, father)

Cravo's testimony reveals the father's concern with his son's future, his fear that his son will develop a deviation of conduct capable of making 
him commit criminal acts, heading on a "road with no return".

Health professionals need to provide orientations on how to cope with the child's aggressive behaviors, as knowledge facilitates the understanding and acceptance of the disease and the treatment adherence. It was observed that the caregiver's education level did not interfere in the care for the child (hygiene, eating, physical care), but interfered in the understanding of the disease, in the way of demanding care and claiming the quality of health services, as verified in another study. ${ }^{7}$ These and other aspects strengthen the need for the family to reorganize its routine to take care of the child, in view of the demand for specialized care, including a routine of medical consultations and multiprofessional monitoring. This fact makes it necessary for the caregiver to make available his/her time to accompany that journey, which in many cases may mean an exclusive dedication to care for the child.

The family members need to attend to the children's needs and promote their appropriate growth and development. Nevertheless, to put this in practice, strategies are needed to cope with the adverse situations and to allow them to work on their anxieties to get to know themselves better and be apt to take care of the others. ${ }^{14}$

The nursing professionals should serve as facilitators of the relatives' adaptation to adverse situations, always keeping in mind that mental health care derives from an intrinsic relation between the services and health professionals, the clients and their families, considering the particularities of each social, economic and cultural context. ${ }^{15}$

In most of the interviewed families, it was evidenced that the caregivers adapted their work hours or quit working with a view to exclusive dedication to the child.

The change was not to have time, because on Tuesdays we take him to the CAPS. On Thursdays, every two weeks, there's the parents group there at the CAPS, and on Friday there's the pocotó [riding therapy]. So every day there's something and there's the socio-educative too. I accompany all of these activities. I used to have a job and I had to quit. I had to change my entire routine, because I used to work. I've always had a job (Girassol, mother).

Only my husband works. At the moment that's all! For reasons due to my child's treatment, because my time is very short. Because, besides the CAPS-i he does, you need to take him to the neurologist, he has specialty treatments due to the neurological problem [...] (Margarida, mother).
The testimonies reveal the changes in the daily family life in function of the child's disease, including the need to readapt the times and quit

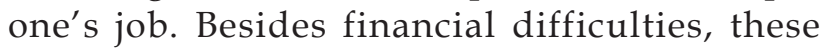
changes can cause a sublimation of the caregivers' interests and personal needs, who often give up looking at themselves, seeking their personal and professional accomplishment to exclusively live in function of the child, which can harm their physical and mental health.

Most of the caregivers were mothers, a fact that supports the literature in the area, affirming that the caregiving role is inherent in the mother, who adapts her work hours or quits her job in disease situations to attend to the child's needs, reducing the family income, which can increase the levels of stress in family relationships..$^{11,16,-17}$

Ah, I can say that everything has changes in my life, because I've always dreamt of being a professional, of having my money. Then I found myself in a situation in which I had to go for something of which I didn't even know what it was. So, for me, it was a very difficult obstacle at first and, in the beginning, I didn't want to accept it either, it was difficult for me to accept it, understand all that, accept and know what he had, and that it is part of my life, and that I should go for that and move on the way it's possible. I tried to work, several times, but as I saw there was no possibility for anyone to stay with him, because he's very agitated, due to the fact that nobody understands his problem and nobody has much patience, so unfortunately I couldn't work [note in field diary: emotional discourse] (Margarida, mother).

In her testimony, Margarida reveals the difficulty to accept the mental disorder and the changes in her life in function of the impacts of this condition. The sadness appeared in her look and tone of voice in the course of the report, especially when mentioning the dream of being a financially independent woman, of having a profession. At the same time, she justified herself, stating that she had found strength in her unconditional love as a mother, to overcome the obstacles and keep up her journey.

In that sense, studies on the team underline that love makes the caregiver find strength to cope with the suffering deriving from the discovery of the disease, the prejudice and the difficulties. ${ }^{4}$

Another aspect addressed in the reports refers to the prejudice in the context of mental health. Many people, due to a lack of knowledge, present prejudiced attitudes when they find out about the mental disorder. 
I have friends, but I no longer go to other people's homes because of his problem; then, they take some distance. My husband's friends used to come here, then they took distance because of my son, because he gets nervous, if he goes to other people's homes he causes trouble [...]. So, I prefer to stay more at home, I stopped receiving visitors too, because it's difficult. At weekends, I used to go out a lot, now I don't anymore, I only go to my mother-inlaw's and my aunt's, to places where the others already know what he has and understand it (Tulipa, mother).

The report unveils a very common aspect in the contexts of families of children with a mental disorder, represented by the social isolation of its members, to hide a situation that causes constraints as well as to protect the child against the lack of understanding and the prejudice.

The prejudice and discrimination stand out, mainly when particular aspect of life with the mental patient become public, as society faces difficulties to accept behaviors that differ from the normality pattern it established., 78

When they are confronted with the unknown universe of the mental illness, the family needs comprehensive care from the health team, aiming to enable it to understand and accept the disease, learning to cope with the child's behavior to preserve the social contact and leisure activities that are essential to maintain the quality of life of its members. Nurses, in turn, play a crucial rule in the substitutive mental health care services, represented by the CAPS-i in this study, being responsible for welcoming, taking care and understanding the suffering according to the singularity of each individual and family. ${ }^{19}$

\section{Feeling and reacting: experiencing the childhood mental disorder}

The discovery of the mental disorder imposes changes in the family structure and the primary caregiver's routine, making countless feelings flourish: concern with the child's behavior, fear, insecurity and sadness. These feelings often end up going by unnoticed to the eyes of the health professional, who needs to get into the family to get to know them and thus be able to support these families, offering the attention and support needed to cope with the disease.

In view of a diagnosis like this, the family feels weakened and guilty and might deny the existence of the disorder, feeling frustrated with the expecta- tions it had about this loved one. The reports of families are common who affirm that, if the problem were physical, they would be able to cope with the situation better. ${ }^{14}$

The need to have someone to share daily events with, as a means to mitigate the pain and share daily care, is evidenced in the participants' reports, in which they highlight the caregivers' emotional burden.

When we're stressed, we talk a lot, blow off steam, relieve that nervousness, that thing that's inside. Sometimes we almost explode too, there are times I lose hope! These days I told the girl [nurse] that sometimes I think I won't stand it, I'll lose hope because of dealing with him (Iris, grandmother).

Ah good Lord! Sometimes I want to get out of here. Yesterday was one of those days, I wanted to disappear from here! The place here is good, but depending on our life situation [...]. But it's good, just the way I am today! If I had a husband, it would be different. Who worked, who provided for the household, then I would dedicate all of my time to them, but I can't (Lírio, mother).

Other people's lack of support in care for the child worsens the primary caregiver's burden, and the despair and physical and emotional exhaustion surpass the hope. ${ }^{11}$ Often the caregiver faces a solitary journey, marked by the need to talk, to share experiences and have someone to listen to the anguish and fears. ${ }^{14}$ The nursing professional's support is essential in that context, valuing sensitive listening and promoting psychosocial rehabilitation actions.

Another aspect evidenced in the participants' reports was the search for explanations for the establishment of the mental disorder in their lives. These explanations are not always rational, but are related to the lack of scientific knowledge and a mystical or fantasized conception of the phenomenon.

Sometimes even I used to fight, because I looked at him and I didn't want to see a child with that kind of disorder [...]. I got depressed because I didn't understand, I used to charge myself, like: 'Why, my God, I had my first son with this problem? Why do I need to go through all this, why do I have to face all this? What did I do to deserve this?' (Margarida, mother).

I raised her, so I'm the mother. You know, I thought it was my fault she had this, but what had I done wrong? Was it some kind of punishment from another life? [...] I was watching my boat sink! I didn't know where to run too. I thought, in a while I'll get out of here crazy, you 
know? I was already feeling lost, as they say (Orquídea, grandmother).

Often, due to a lack of precise information and further knowledge on the mental problem, the mother looks for explanations in her actions, blaming herself for the child's disease, attributing the fact to some kind of divine punishment, making the acceptance of the disease more difficult. Besides the reports, the manifestations of fatigue, perceptible in the interviewees' posture and tone of voice, contributed to the expression of feelings of helplessness, discouragement and profound sadness, making the interviewees reveal the desire to give up.

Thus, the family attempts to understand where it went wrong, feeling guilty for the child's disease, at the same time as it faces the temporal mismatch and feeling of loss due to communication and interaction difficulties. ${ }^{14}$ The lack of knowledge on the meaning of this disease and the lack of clarity about what happens with people affected by this condition make the family feel lost with regard to what attitudes to adopt with its loved one., ${ }^{7,17}$

The guilt shows to be one of the most visible marks in the lives of families affected by a mental disorder, making them look for errors they may have committed in the past, in the attempt to explain the appearance of the disorder. Thus, they look for a concrete explanation for a reality they consider unacceptable, looking for someone to blame for a fact to which guilt does not apply. ${ }^{18}$ Then, the caregivers look for devices or strategies that help them to cope with the child's disease. One of these strategies is to develop activities that get them out of the routine care.

Look, to tell you the truth, I feel really bad, I don't like to go through this. So I tried to do something for the better, invest more in me, focusing on something so as not to freak out. Because if we lose it, if we lower our heads [...] sometimes we want to get isolated, want to be alone, you know? We want to disappear, open up a hole and get in there! But it's not like that, we have to move on... it's complicated, but you have to raise your head, get up each day and say: 'today I'm gonna raise my head, conquer my day' (Girassol, mother).

The mental illness compromises the family's emotional structure and the caregivers look for coping strategies. Girassol reported taking a sewing course for her to work at home, conciliating her professional activities with care for her child.

Often, the return to the job world through the development of paid work rescues a condition the caregiver possessed before the emergence of the disease, making this family caregiver start to feel useful. This recovery of self-esteem can have an invigorating effect, strengthening this family member to proceed on this journey to accompany the therapeutics.

In addition, the mental disorder is permeated by stigma and prejudice, reflecting a posture of rejection of everything and everyone who escapes from the established standard of normality.

Thus... people, they got kind of frightened, like, to go deeper, to try and understand this, it's better not to understand it. And it's the same situation, my husband is a dumb person. He has never faced this, so, at first, he refused to accept that our son had a problem! In fact I faced all of this alone, my entire family, nobody knew the reason why this starts. The 'why' this happens! So, like, I went in search of solutions in another way, people who know (Margarida, mother).

In this testimony, the non-acceptance of the presence of the intra-family mental disorder is observed, largely motivated by the lack of knowledge on the disease. In some cases, the family is afraid of being judged for the child's attitudes as, often, society blames the child's aggressive or beyond normal behavior to educational errors the family committed, or as the mirror of the parents' attitudes.

I have support, but I hadn't before! It was just criticism! Sometimes, people used to say that someone in the family did the same thing, things the children did, they always said that, then, someone was doing it for them. And there was always a reference framework, that the family should be like that. So, they didn't know but already judged. For us it was very difficult (Girassol, mother).

Thus, the family is subject to prejudiced and discriminatory attitudes that leave social marks. ${ }^{7}$ These attitudes by the community also provoke fear and indignation in the parents who, as a rule, distance the child from social life in the attempt to avoid proximity with other children out of fear of aggression.

Fear is a great obstacle and limits the interpersonal relationship, linked to feelings of shame and constraint because of the child's inappropriate behaviors, which hampers contact and social interaction. ${ }^{18}$

I think a lot of him being in the classroom without being criticized, without being rated [...] Because he reaches the gate and the parents already say: 'Ai, he's going to hit my son!' He gets marginal, you know? Now, 
getting into the classroom, sitting down and doing his things, it's kind of difficult. But I have hopes he'll manage (Girassol, mother).

Families with a child with a mental disorder at its heart experience a whirlwind of feelings that range from initial denial to fear of social contact to expectations and doubts about the future. In that sense, the nurses and other health professionals are responsible for acknowledging, in these families and their particularities, the essential information sources to plan care. The family should lie at the base and serve as the final destination of this care process, playing a protagonist role in the construction of quality of life for children with mental disorders and their family members.

A study involving nurses from a psychosocial care center revealed limited knowledge on the Psychiatric Reform, and the lack of this knowledge can interfere in the quality of the care they deliver. Therefore, it is fundamental for nursing to gain competencies and skills to attend to this population's needs, based on its own knowledge. ${ }^{20}$ Thus, the nurses need to know the Psychiatric Reform movement for its principles to support their practice, gaining the knowledge needed to grasp and understand the singularity of each individual and each family, centering their care on the family group.

\section{FINAL CONSIDERATIONS}

The categories that emerged from the data analysis showed the aspects of daily life with the child, the feelings the family members experienced and the family's reaction to the child with mental disorder. They also evidenced care centralized on the mother figure, her protagonist role in monitoring and decision making about health and the treatment of the child with mental disorder.

The discovery of the mental disorder in childhood modified the routine of these children's family, entailing the need for adaptations to the new situation. In most cases, the preferred caregivers were obliged to leave their job to exclusively focus on child care and, in some cases, also deprived themselves of leisure and social activities, which are essential to maintain their physical and mental health.

The reports also revealed the difficulties with social contact in the reality of these children and their families and the caregivers' feelings of unpreparedness to cope with the children's aggressive behaviors. The participants said that the children's aggressive behavior is the main cause of the intra and extra- family prejudice they are victims of and, therefore, their attempts towards isolation from social life.

Mental illness is still a source of prejudice and discrimination today, which hampers its understanding and acceptance in society, causing suffering for the child and the family. Health professionals and particularly nurses should get to know and enter this reality, developing sensitive listening, guiding, supporting and solving these families' doubts to promote their empowerment as, equipped with information and knowledge on mental illness, each family can construct a more balanced trajectory in search of its autonomy.

The role of nursing as a facilitator of this process is of fundamental importance to relieve fears, reduce anguish and stimulate the feeling of family security. Thus, the nurses' effective participation in work with families of mental patients, whether children or adults, is not a reality yet. The discourse about the lack of preparation still continues, based on the fact that, in the course of decades, mental health teaching in nursing schools has been linked with the idea of psychiatric internment. Hence, nurses are responsible for seeking mechanisms to modify this paradigm, updating their concepts and practices to qualify care for these clients, guided by the ideals of social reinsertion, freedom and familycentered care.

Finally, despite some limitations, deriving from the fact, for example, that the families were indicated by health professionals, it was verified that all of them have lived with childhood mental disorders for more than a year, long enough to qualify their experiences. Therefore, the results found not only support family-centered nursing care, but can also encourage new reflections on the theme, which has not been much explored yet, and lead to further studies that do not only focus on the experience of families of children with mental disorders, but also on the support networks and strategies used to cope with this condition.

\section{REFERENCES}

1. Assis SG, Avanci JQ, Pesce RP, Ximenes LF. Situação de crianças e adolescentes brasileiros em relação à saúde mental e à violência. Cien Saude Colet. 2009 Mar-Apr; 4(2):349-61.

2. Ministério da Saúde (BR). Portal da Saúde. O que é Reforma Psiquiátrica [página na Internet]. Brasília (DF); 2013 [atualizado 2013 Jan 20; acesso 2013 Nov 20]. Disponível em: http://portal.saude.gov.br/ portal/saude/visualizar_texto.cfm?idtxt=33929 
3. Delvan JDS, Portes JRB, Cunha MP, Menezes M, Legal EJ. Crianças que utilizam os serviços de saúde mental: caracterização da população em uma cidade do sul do Brasil. Rev Bras Crescimento Desenvolvimento Hum. 2010; 20(2):228-37.

4. Monteiro ARM, Teixeira LA, Silva RSM, Rabelo KPS, Tavares SFV, Távora RCO. Sofrimento psíquico em crianças e adolescentes - a busca pelo tratamento. Esc Anna Nery. 2012 Jul-Set; 16(3):523-29.

5. Dutra VFD. O cuidado oferecido a pessoas que vivenciaram a experiência da desinstitucionalização. Cienc Cuid Saude. 2011 Abr-Jun; 10(2):218-25.

6. Galera SAF, Zanetti ACG, Ferreira GCS, Giacon BCC, Cardoso L. Pesquisas com famílias de portadores de transtorno mental. Rev Bras Enferm. 2011 Jul-Ago; 64(4):774-8.

7. Estevam MC, Marcon SS, Antonio MM, Munari DB, Waidman MAP. Living with mental disorders: family members' perspective have on primary care. Rev Esc Enferm USP. 2011; 45(3):679-86.

8. Brasil. Estatuto da Criança e Adolescente. Brasília (DF): Edição 7; 2012.

9. Bardin L. Análise de conteúdo. São Paulo (SP): Edições 70; 2011.

10. Martins RV, Rossetto M, Sartori QDN, Pinto EC, Van Der Sand ICP, Hildebrandt LM. Ações de saúde mental na região norte do Rio Grande do Sul, Brasil. Rev Gaúcha Enferm. 2012 Mar; 33(1):11-8.

11. Silva MDAS, Collete N, Silva KDL, Moura FMD. Cotidiano da família no enfrentamento da condição crônica na infância. Acta Paul Enferm. 2010; 23(3):359-65
12. Scivoletto S, Borati MA, Turkiewicz G. Emergências psiquiátricas na infância e adolescência. Rev Bras Psiquiatr. 2010; 32(supl II):112-20.

13. Relva IC, Fernandes OM, Alarcão M. Violência entre irmãos: uma realidade desconhecida. Rev Interam Psicol. 2012 Set-Dez; 46(3):375-84.

14. Borba LO, Paes MR, Guimarães AN, Labronici LM, Maftum MA. The family and the mental disturbance carrier: dynamics and their family relationship. Rev Esc Enferm USP. 2011; 45(2):442-9.

15. Cardoso L, Galera ASF. Mental health care today. Rev Esc Enferm USP. 2011; 45(3):687-91.

16. Marini A, Martins MRI, Vigãno A, Marques Filho AB, Pontes HER. Sobrecarga de cuidadores na psiquiatria infantil. Rev Neurocienc. 2010; 18(3):300-6.

17. Bessa JB, Waidman, MAP. Family of people with a mental disorder and needs in psychiatric care. Texto Contexto Enferm [online]. 2013 Jan-Mar; [acesso 2013 Nov 10]; 2(1):61-70. Disponível em: http://www. scielo.br/pdf/tce/v22n1/pt_08.pdf

18. Vicente JB, Mariano PP, Buriola A, Paino M, Waidman MAP, Marcon SS. Aceitação da pessoa com transtorno mental na perspectiva de familiares. Rev Gaúcha Enferm. 2013; 32(2):54-61.

19. Kondo EH, Vilella JC, Borba LO, Paes MR, Maftum MA. A nursing team's approach to users of a mental health emergency room. Rev Esc Enferm USP. 2011; 45(2):501-7.

20. Dias CB, Silva ALA. The profile and professional practice of nurses in a psychosocial care services. Rev Esc Enferm USP. 2010; 44(2):469-75. 